Kathmandu School of Law Review (KSLR),

Volume 8, Issue 1, 2020, pp 1-20

https://doi.org/10.46985/kslr.v8i1.2125

(C) KSLR, 2020

\title{
Exclusivity in Times of a Public Necessity: Balance of Interests in South Asia's Compulsory Licensing Regime
}

\author{
Neha Dhavalikar* \& Ashok Pandey**
}

\begin{abstract}
The catastrophic impact of the COVID-19 pandemic on every facet of buman life has made the requirement of a pharmaceutical breakthrough in the form of a vaccine more urgent than ever. The urgency has led to a bundred plus researches being underway, with tremendous amounts of capital and intellect invested. The vaccine being an invention, invites patent regulations and the rights of the patent holder associated with the invention. However, given the urgency of the situation, countries need to ensure hassle free access to the vaccine. Here, Compulsory Licensing regulations would play an important role. Beginning with a historical background of Compulsory Licensing under TRIPS, the authors analyse its subsequent amendment keeping in view the right of countries to give primacy to public health over intellectual property protection. The authors then bighlight the diverse legislative positions of Compulsory Licensing in South Asia through the lens of the TRIPS position. The authors also comment upon Patent Pools, a comparatively new concept in the area of public health which is gaining spotlight. Further emphasis has been laid on keeping administrative impediments minimal with regards to the working of the intellectual property. This is important since firstly, the majority of the attempts underway are a collaborative innovation involving multiple stakeholders and secondly, multiple patent applications could be filed for different parts of a single invention leading to complexities while licensing. Finally, suggestions have been given as to how the patent regulations could be worked so as to maintain a balance between the rights of the patent holder and public health.
\end{abstract}

The COVID-19 pandemic has wreaked havoc by disrupting normal life, putting immense strain on the healthcare systems, and by bringing the economies of even the most developed countries in the world to a standstill. The alarming increase in the number of infected persons and death rates have shown the lack of preparedness and vulnerabilities of every country, regardless of their economic strength and advanced

* Neha Dhavalikar is a B.A. LL.B 4th year student at Indian Law Society Law College, Pune, India. She can be reached atdhavalikarneha@gmail.com.

** Ashok Pandey is a B.A. LL.B 4th year student at Indian Law Society Law College, Pune, India. He can be reached at pandeyashok0198@gmail.com.

This paper was awarded the Best Paper in the International Research Paper Writing Competition, which was organized by Kathmandu School of Law Review, Amnesty International Fusion Youth Network, and the Cognition Club. 
health care facilities. Although several guidelines were suggested, few countries have succeeded in flattening the curve.

The recent lockdown relaxations brought forth by many countries in order to address the concerns of economic downfalls have only brought a resurgence in the number of cases. What remains now, is pharmaceutical intervention. A vaccine is a unique measure which can help in preventing such a resurgence as it enables individuals to develop immunity to diseases without contracting them. ${ }^{1}$ Vaccinated individuals can be protected from the disease for life, thereby reducing the risk of contagion and recurrence of the disease.

Multiple pharmaceutical companies, academic research centres and government bodies have started working on the development of a COVID-19 vaccine, and over 100 studies are currently underway. ${ }^{2}$ The unprecedented magnitude of the pandemic has led to a race to develop a cure, with promises being made to deliver one by as early as $2021 .{ }^{3}$ The usual time frame for the development of a vaccine is 10 years, and the cost of development goes as high as $\$ 500$ million. ${ }^{4}$ However, given the catastrophic impact of the pandemic, immediate results are a need of the hour. The significantly shorter time frame implies significantly higher costs of development (estimated to go up to $\$ 2-3$ billion)..$^{5}$ A manufacturer who invests capital into the creation of a vaccine would aim to recover at least the cost of production in case of a breakthrough. Hence, it is highly probable that manufacturers would use patent regulations in order to recover the cost of production or even earn profits.

The estimated cost of one round of treatment by Institute for Clinical and Economic Review is $\$ 4500^{6}$ which is unacceptable in most countries. Although several pharmaceutical companies such as Johnson and Johnson have promised to sell the drugs at a not-for-profit price, ${ }^{7}$ it does not imply that everyone will be able to afford it. Several countries have severely constrained healthcare budgets which can potentially make these vaccines inaccessible to low-income individuals and underdeveloped countries. Given the public health emergency and widespread income disparity, some companies have decided to enter into voluntary licensing agreements like Gilead did

\footnotetext{
1 'Vaccines: The basics', Centers for Disease Control and Prevention, available at https://www.cdc.gov/vaccines/ vpd/vpd-vac-basics.html, accessed on 2 August 2020.

2 Douglas Broom, ' 5 charts that tell the story of vaccines today', World Economic Forum, 2 June 2020, available at https://www.weforum.org/agenda/2020/06/vaccine-development-barriers-coronavirus/, accessed on 2 August 2020.

3 Ibid.

4 Broom (n 2).

5 '30 groups in India working on COVID-19 vaccine, development may cost \$2-3 billion if done in a year', DNA, 28 May 2020,available at https://www.dnaindia.com/health/report-30-groups-in-india-workingon-covid-19-vaccine-development-may-cost-2-3-billion-if-done-in-a-year-2826266, accessed on 2 August 2020.

6 Divya Shekhar, 'The race to make a Covid-19 vaccine in India', Forbes India, 21 May 2020, available at https:// www.forbesindia.com/article/coronavirus/the-race-to-make-a-covid19-vaccine-in-india/59547/1, accessed on 2 August 2020.

Ibid.
} 
for their flu drug, Remdesivir. However, 140 world leaders have demanded the free distribution of COVID-19 vaccines in lieu of the urgent need to resolve the public health crisis. ${ }^{8}$

In such a situation, a balance will have to be achieved between the exclusivity under patents and the right to public health. The provision relating to Compulsory Licensing, and the initiative of Patent Pools, in the opinion of the authors, comes closest to achieving this balance.

However, the Compulsory Licensing provisions across jurisdictions are varying. For example, the March-in rights of the Bayh-Dole Act in the United States have very limited intervention in the patent rights which only extend to those patents which are majorly funded by the federal government. The European Union regime, however, promotes the grant of Compulsory Licenses for exporting medicines to countries facing public health problems. Even among South-Asian countries, there is a lot of disparity regarding the scope and grounds of Compulsory Licensing.

Keeping this into consideration, the paper aims to analyse the prevailing Compulsory Licensing regimes across different South-Asian countries, and its efficacy in ensuring a balance between the rights of a patentee and the public health necessities.

The paper shall begin with the historical background of Compulsory Licensing and its usage in ensuring public health. This shall be followed by a holistic analysis of the Trade Related Aspects of Intellectual Property Rights Agreement, 1994 (TRIPS Agreement) with regards to the Compulsory Licensing regime which it recognizes for its Member countries.

The authors shall then critique the Compulsory Licensing regimes across different South Asian countries from the lens of the TRIPS Agreement and the Doha Declaration in a manner that such implementation and interpretation support the W'TO Members' right to protect public health with particular emphasis on promoting access to medicines for all.

Although Patent Pools are comparatively new in the public health regime, the WHO opined that it could be an effective tool to ensure access to medicines for SARS in 2005 itself. ${ }^{9}$ However, the pharmaceutical industry and many developed countries are cynical about this approach. ${ }^{10}$ Their cynicism shall be addressed by analysing this practice and suggesting probable measures for the same.

\footnotetext{
8 Broom (n 2).

9 James Simon and others, 'Managing severe acute respiratory syndrome (SARS) intellectual property rights: the possible role of patent pooling', Bulletin of the World Health Organization p. 707, volume 83:9, 2005, p. 708, available at https://www.who.int/bulletin/volumes/83/9/707.pdf?ua=1, accessed on 24 July 2020.

10 Sarah Neway, 'WHO Patent Pool for potential COVID-19 products is nonsense', The Telegraph, 29 May2020, available athttps://www.telegraph.co.uk/global-health/science-and-disease/patent-pool-potential-covid19-products-nonsense-pharma-leaders/, accessed on 13 July 2020.
} 


\section{Historical Background of Compulsory Licensing for Public Health}

Compulsory Licensing has a history which dates back to the 1830s and which gained popularity during the British anti-patent movement of 1850 s and 1860 s. ${ }^{11}$ It received international recognition for the first time at the Paris Convention of $1883 .{ }^{12}$ Article 5A (2) of the Convention reads the following:

(2) Each country of the Union shall have the right to take legislative measures providing for the grant of compulsory licenses to prevent the abuses which might result from the exercise of the exclusive rights conferred by the patent, for example, failure to work.

The Paris and Berne Conventions laid the foundation for recognizing the importance of intellectual property and the adoption of the TRIPS Agreement, 1994 was the first major breakthrough. It recognizes the importance of protecting Intellectual Property Rights for the development of a conducive atmosphere for trade and commerce. Emphasis was laid on making sure that it has adequate provisions to address the concerns of Intellectual Property holders whose rights are infringed. ${ }^{13}$ A provision for compulsory Licensing was included in Article 31 of the Agreement.

Under a Compulsory License, an individual, government or any person designated by the government has the right to exploit a patent without the consent of the patent holder, ${ }^{14}$ provided that certain conditions have been met which justify such exploitation of the patent. The Patent holder is also entitled to remuneration. ${ }^{15}$

In the majority of modern legislative frameworks, the power to decide whether a patent should be exploited under a Compulsory License rests with the government. While exercising this power, the government may either exploit the patent on its own, or give the right to a designated third party. In the majority of jurisdictions, negotiations for a voluntary license on reasonable commercial terms need to take place before the application for a Compulsory License. This is laid down in Article 31(b) of TRIPS.

It should however be noted, that the Compulsory Licensing provision under the TRIPS Agreement had a very narrow scope. In fact, provisions such as Article 31(f) of the Agreement mandated that any patented product being used under a compulsory license could only be made available in the domestic markets. Finally, in 2001 the provisions of the TRIPS Agreement were revisited and it was found that there was little in it for the poor, underdeveloped countries which lack means to manufacture essential medicines in times of a public emergency.

\footnotetext{
11 Adrian Johns, Piracy: The Intellectual Property Wars from Gutenberg to Gates, University of Chicago Press Books 2010, Chicago, 1st edition, 2010, p. 274.

12 Paris Convention for the Protection of Industrial Property, 26 April 1970, 828 U.N.T.S. 305, Paris, 20 March 1883, art. 5.

13 'Overview: the TRIPS Agreement', World Trade Organization, available at https://www.wto.org/english/ tratop_e/trips_e/intel2_e.htm\#standards, accessed on 10 July 2020.

14 Agreement on Trade-Related Aspects of Intellectual Property Rights, 1 January 1995, 1869 U.N.T.S. 299, Uruguay, 15 April 1994, art. 31.

15 Ibid, art. 31(h).
} 
The Doha Declaration recognized this plight of the poor and underdeveloped countries and instructed the TRIPS Council to find an expeditious solution. ${ }^{16}$ For the first time, a sovereign's right to protect public health was given primacy over Intellectual Property Rights. It was also for the first time, that a core WTO agreement was amended. The amendments were finally accepted by the majority Members on $3^{\text {rd }}$ December 2005. India was the first South-Asian country to announce that its patent laws are compatible with the amendments accepted. ${ }^{17}$ Although the target was to bring the amendment into force by 2005, deadlines kept getting extended and the amendment finally came into force on 30 January $2017^{18}$. All South Asian countries except Afghanistan, Bhutan (a non-member of the WTO) and the Maldives have enforced the amendments.

The introduction of these amendments was primarily a result of monopolization of antiretroviral drugs (which are essential for the treatment of HIV/AIDS) by the US pharmaceutical companies. This led to the sacrifice of millions of lives. The United States had a strict Compulsory Licensing regime in place and it considered the TRIPS Agreement to be nothing more than "a minimum standard of protection."19 Due to the monopolization, a year's treatment of HIV/AIDS cost anything between $\$ 10,000$ and $\$ 15,000$. This led to the loss of millions of lives in the poor sub-Saharan countries for 10 years.

At this juncture, India's prominent pharmaceutical giant Cipla intervened and offered to give treatment for HIV/AIDS in the form of a "drug cocktail" of three antiretroviral drugs at a price of $\$ 350$ for a year's treatment. Not only AIDS, but the drug monopolization attempted by the US also increased the prices of medicines for Malaria and Tuberculosis. ${ }^{20}$

The fear of US sanctions made it impossible for the countries to utilize the Compulsory Licensing provisions. Moreover, even if Compulsory Licenses were granted, a lot of underdeveloped countries did not have the ability to produce the pharmaceutical products. Therefore, the TRIPS General Council decided to waive Article 31(f) of the TRIPS Agreement and laid down Article 31bis. This amendment laid down the conditions under which a pharmaceutical product could be exported to other countries. After these amendments were brought forth, a lot of African countries took advantage of it to improve their situation which had worsened due to HIV/AIDS. ${ }^{21}$

16 Implementation of Paragraph 6 of The Doha Declaration on The TRIPS Agreement and Public Health, 1 September 2003, WTO General Council Meeting of 30 August 2003, Geneva, para. 4.

17 'Members OK amendment to make health flexibility permanent', World Trade Organisation, 06/12/2005, available at https://www.wto.org/english/news_e/pres05_e/pr426_e.htm, accessed on 10 July 2020.

18 'Amendment to the Agreement on Trade Related Aspects of Intellectual Property Rights (TRIPS)', World Trade Organisation, 23 January 2017, available at,https://www.wto.org/english/tratop_e/trips_e/ tripsfacsheet_e.htm, accessed on 10 July 2020.

19 Neway (n 10).

20 'AIDS and essential medicines and Compulsory Licensing', Access Campaign, 26/02/1999, available at https://msfaccess.org/aids-and-essential-medicines-and-compulsory-licensing, accessed on 11 July 2020.

21 Bob Aroture, '10 examples of the use of Compulsory Licenses for AIDS-Related Pharmaceuticals in Africa', Nigerian Law Intellectual Property Watch Inc., 02 August 2013, available athttps://nlipw.com/10examples-of-the-use-of-compulsory-licenses-in-africa-2/, accessed on 12 July 2020. 


\section{Applicability in Times of Covid-19}

As it has already been highlighted in the introductory chapter, the potential costs of a COVID-19 vaccine could be way too high for the poor and developing countries. Moreover, the United States has already set its monopolistic ball rolling by buying all of Remdesivir's three months' supplies. ${ }^{22}$ The United States and United Kingdom in fact, were the only dissenters in the World Health Assembly's resolution proposed by Costa Rica and Chile to make the COVID-19 vaccines and medicines available like a public good by establishing a technology pooling initiative. ${ }^{23}$

Since the pandemic has adversely affected even the most stable and powerful economies, it is possible that they might use their early breakthrough in inventing a vaccine as a tool to re-establish their dominance. The landmark judgement of Natco v. Bayer ${ }^{24}$ in India upheld the validity of a compulsory license for a cancer drug "Navaxar". Since then, India has continuously featured in the Priority Watch List of the United States Trade Representative's Special 301 Report. This report threatens to impose sanctions on any country which grants compulsory licenses for its patented products. ${ }^{25}$

The COVID-19 pandemic has had widespread implications on all walks of life. In fact, according to a UN Report, the pandemic is expected to set back the battle against AIDS by 10 years. ${ }^{26}$ Moreover, it also projects that the prices of medicines from India, in the midst of the pandemic, could increase by $10-25 \% .{ }^{27}$ Goal 3 of the Sustainable Development Goals (SDG) requires all the countries to "Ensure bealthy lives and promote well-being for all at all ages".

For achieving this goal, universal access to any COVID-19 vaccine is very important. This is not only because a large number of people are dying because of the virus, but also because a number of other essential medicine facilities in the world have come to a standstill. According to the United Nations, the pandemic has interrupted childhood immunization programs in more than 70 countries. Service cancellations are expected to lead to a $100 \%$ increase in Malaria deaths in Sub-Saharan Africa. ${ }^{28}$

22 Bianca Nogrady, 'US buys 3 months' worth of Remdesivir stocks', Medical Republic, 1 July 2020, available athttp://medicalrepublic.com.au/liveblog1july2020/30950, accessed on 13 July 2020.

23 Neway (n 10).

24 Bayer Corporation v. Natco Pharma Ltd., Intellectual Property Appellate Board, Chennai, 2013, SCC OnLine IPAB 25, p. 25.

25 Reji K. Joseph, 'US tries to thwart TRIPS flexibilities in the midst of a pandemic', Livemint, 1 May2020, available athttps://www.livemint.com/opinion/online-views/us-tries-to-thwart-trips-flexibilities-in-themidst-of-a-pandemic-11588320583933.html, accessed on 14 July 2020.

26 Kate Kelland, 'Faltering AIDS battle risks 10-year setback from COVID-19, UN warns', Reuters, 6 July 2020, available at https://www.aol.com/article/news/2020/07/06/faltering-aids-battle-risks-10-yearsetback-from-covid-19-un-warns/24547777/, accessed on 14 July 2020.

27 'Global HIV and AIDS- 2020 Factsheet', UNAIDS, available at https://www.unaids.org/en/resources/ fact-sheet, accessed on 14 July 2020.

28 'Goal 3: Ensure healthy lives and promote well-being for all at all ages', United Nations Department of Economic and social affairs-Sustainable Development, available at https://sdgs.un.org/goals/goal3, accessed on 1 August 2020 . 
The constant rise in the number of COVID affected individuals and the impact of the virus on vital healthcare facilities makes it more important than ever, to use the TRIPS Agreement flexibilities in a way that it ensures access to medicine for all. Moreover, all 10 candidate vaccines which are in phase 1 and 2 of human trials are being developed in the world's most powerful economies ${ }^{29}$ who might not choose to take a humanitarian approach.

\section{Compulsory Licensing Under the TRIPS Agreement}

Article 31 of the TRIPS Agreement provides for "other use without authorization of the right holder where the law of a member country allows for the subject matter of a patent to be used without the authorization of the right holder including use by the government or third party authorized by the Government." It applies when a country has established a compulsory licensing or government use system and it gives recognition to the right of a Member to grant a compulsory license. ${ }^{30}$

Article 31 provides a set of conditions and limitations for granting of such licenses. Compulsory licenses can address public health emergencies such as COVID-19, by ensuring access to cheap drugs by reducing prices and increasing consumer welfare. Some argue that compulsory licenses could reduce the expected profit of the patent holder and undermine their incentive to invest in research and development. ${ }^{31}$ However, Scherer's statistical findings of the R\&D expenditure show that no such negative effect can be seen on companies subjected to compulsory licenses. ${ }^{32}$ On the contrary, there was a significant rise in such companies' $\mathrm{R} \& \mathrm{D}$, relative to companies of a comparable size which were not subjected to such licenses. ${ }^{33}$

Article 31 includes some possible grounds for the grant of compulsory licenses. These grounds include "national emergency" or "extreme urgency" and "public non-commercial use". The other grounds available are beyond the scope of the topic. TRIPS Members can determine whether a situation is a "national emergency" or "extreme urgency" while granting a compulsory license. Paragraph 5(c) of the Doha declaration confirms the same and recognizes that public health crises relating to diseases such as tuberculosis, malaria, HIV/AIDS and other epidemics can constitute a national emergency or extreme urgency. This would also include a pandemic such as COVID-19 in its scope. In such situations, there is no obligation to enter into prior negotiations with the patent owner

29 'Draft Landscape of COVID-19 candidate vaccines', World Health Organisation, 31 July 2020, available athttps://www.who.int/publications/m/item/draft-landscape-of-covid-19-candidate-vaccines, accessed on 2 August 2020.

30 Carlos Correa, Trade Related Aspects of Intellectual Property Rights: A Commentary on the TRIPS Agreement, Oxford University Press, UK, 1st edition,2007, p. 314.

31 Richard Rozeck \& Renee Rainey, 'Broad-based Compulsory Licensing of pharmaceutical technologies Unsound public policy', The Journal of World Intellectual Property p. 463, volume 4:4, 2005, p. 471.

32 F. Michael Scherer, 'Comment'. in Anderson and Gallini (eds), Competition Policy and Intellectual Property Rights in the Knowledge- based Economy, University of Calgary Press, Calgary, 1st edition, 1998, p. 163.

33 Ibid. 
under Article 31(b).

Furthermore, the use of the word "epidemic" in Article 31 indicates that the problem may not necessarily be a short-term problem and includes long-lasting situations as well. ${ }^{34}$ The measures adopted under Article 31 may be imposed for as long as the circumstances under which the license was granted persist. Therefore, the scope of this Article is perfectly compatible with the prevailing COVID-19 situation.

If a country objects to the grant of a Compulsory License by another country on the ground that no emergency or urgency exists, paragraph 5(c) of the Doha Declaration imposes the burden to prove that no such emergency exists upon the objecting country. Member states granting such compulsory licenses need not follow any formalities.

Public non-commercial use refers to government use or acts done by government authorization without the patent holder's consent. This could either be done by government departments or through a designated third-party contractor. Public noncommercial use does not prevent the government agency from appointing a commercial contractor, or an agent to exploit the patent(s) on behalf of the government. National laws can limit the remedies available against the government.

Article 8 of the TRIPS Agreement states that the Members have the right to adopt measures necessary to protect public health nutrition. ${ }^{35}$ It further states that they have the right to promote public interest in the sectors of vital importance to the socioeconomic and technological development of the country. However, such measures must be consistent with the provisions of the TRIPS Agreement. Therefore, compulsory licenses can be granted for reasons of public interest, or to satisfy objectives of public health. British law permits grant of compulsory licenses on the grounds of refusal to deal which is based on the essential facilities doctrine. ${ }^{36}$

A detailed elaboration on the legislative positions on Compulsory Licensing in the South-Asian countries is given subsequently.

\section{Conditions for grant of compulsory license}

Compulsory licenses should be granted on the basis of individual merits of a case. However, certain parameters for the grant of compulsory licenses may be established for certain categories of products required to address specific needs, such as an epidemic. ${ }^{37}$ In case of extreme urgency, the patent holder must be notified as soon as reasonably practicable that their patent is in use without their consent. The patent shall be exploited only for the specific purpose for which the Compulsory License was granted.

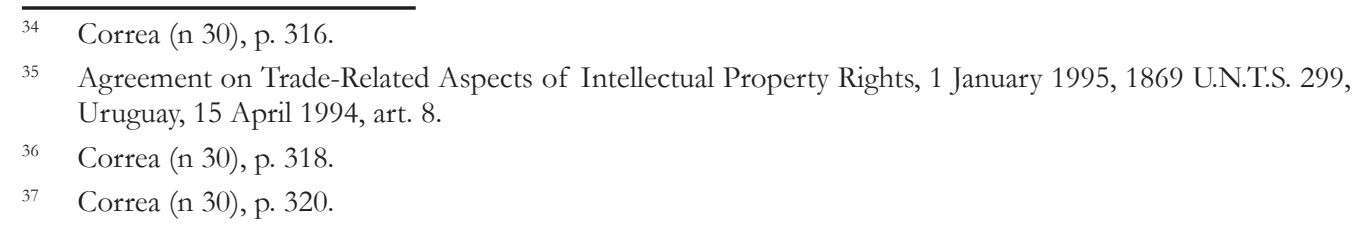


Prior to adoption of the Doha Declaration, Compulsory License could be granted predominantly for the supply of the domestic market as per Article 31(f). However, this provision did not specify when the domestic market is deemed to be "predominantly supplied". National laws could apply different standards to interpret these words based on different metrics such as sales, economic value, volume, etc.

In their submission to the TRIPS Council, the developing countries argued that article 31(f) acted as a barrier to supply to foreign markets. ${ }^{38}$ This became a focal point in the adoption of paragraph 6 of the Doha Declaration. The rationale behind paragraph 6 is that only few developing countries have some manufacturing capacity in pharmaceuticals. Hence, many countries could face difficulties in acquiring medicines at an affordable price. The determination of the sufficiency of manufacturing capability is self-assessed.

However, it is believed that modern pharmaceuticals still bear a print of the colonial mindset. ${ }^{39}$ Scholars such as K. M Gopakumar are of the belief that the TRIPS Agreement is a "classic case of corporate capture of international law" ${ }^{40}$ Not only is the global south seen as an emerging laboratory for low-cost clinical trials by the global north, ${ }^{41}$ but also most South Asian countries lack sufficient manufacturing capacity in the field of pharmaceuticals.

According to Carlos M. Correa, Afghanistan, Bangladesh, Nepal, Pakistan and Sri Lanka have reproductive capabilities where the finished products could be produced in these countries using imported ingredients only. Whereas Bhutan and Maldives have no pharmaceutical industry of their own. India is the only South-Asian country with innovative capabilities. ${ }^{42}$

Before the full-fledged enforcement of the TRIPS Agreement, countries such as India, which produced generic versions of medicines at a fraction of the price of the patented products; could export them to other countries. ${ }^{43}$ Member countries could issue a compulsory license and import the drugs from such countries. However, this was no longer possible after 2005, i.e., when the TRIPS Agreement became fully enforceable. Countries with insufficient manufacturing capacity could not ensure access to medicines through licenses or imports.

\footnotetext{
38 Council Discussion on Access to Medicines: Developing country group's paper, IP/C/W/296, para. 28.

39 Abraar Karan, 'Opinion: It's Time To End The Colonial Mindset In Global Health', Goats and Soda, 30 December 2019, available at https://www.npr.org/sections/goatsandsoda/2019/12/30/784392315/ opinion-its-time-to-end-the-colonial-mindset-in-global-health, accessed on 24 January 2021.

40 K. M. Gopakumar, 'Twenty years of TRIPS Agreement and access to medicine: a development perspective', Indian Journal of International Law, p. 367, volume55, 2015.

41 Rajeshwar Chigullapalli and Feroz Zaheer, 'Asia- The Emerging R\&D hub', PLG Group, available athttp:/ / plg-group.com/wp-content/uploads/2014/03/Asia-ermering-pharma-RD-Hub-R-Chigullapalli-F.Saheer.pdf, accessed on 24 January 2021.

42 Carlos M. Correa, 'Implication of the Doha Declaration on the TRIPS Agreement and Public Health (2002) Essential Drugs and Medicine Policy', World Trade Organisation, available at https://www.who.int/ medicines/areas/policy/WHO_EDM_PAR_2002.3.pdf, accessed on 3 August 2020.

43 Correa (n 30), p. 321.
} 
In order to address these problems, the General Council adopted the Decision of August $2003^{44}$ which gave rise to amendments to the TRIPS Agreement. This Decision waived off Article 31(f) with respect to pharmaceutical products. It also inserted Article 31 bis which laid down the conditions under which patented products could be exported using the Compulsory Licensing provision. Article 31 bis has been discussed in detail subsequently.

Article $31(\mathrm{~g})$ sets forth the principle that "compulsory licenses are liable to be terminated when the circumstances which led to the grant of such compulsory license are unlikely to recur." 45 Therefore, the License granted cannot be terminated when there is a possibility of resurgence in the number of COVID-19 cases.

Article 31(h) states that the title holder of the patent should be paid adequate remuneration in the circumstances of each case, by taking into account the circumstances of each case and economic value of the authorization. The economic value depends upon the size of the market, the maturity of the technology, rate of obsolescence, degree of competition, availability of substitute products and the coverage of the patent. ${ }^{46}$ National laws need to determine whether the remuneration is adequate by taking these factors into consideration.

According to the Remuneration Guidelines of Non-voluntary Use of a Patent on Medical Technologies ${ }^{47}$, some methods of calculation to determine an adequate level of remuneration are as follows:

- "The 1998 Japan Patent Office guidelines allow for normal royalties of 2 to $4 \%$ of the price of the generic product and can be increased by as much as $2 \%$, for a range of 0 to $6 \%$.

- The 2001 UNDP Human Development Report proposed a base royalty rate of $4 \%$ of the price of the generic product. This can be increased by $2 \%$ depending on factors such as innovativeness and the role of the government in paying for research and development.

- The 2005 Canadian Government Royalty Guidelines for compulsory licensing of patents for export to countries that lack manufacturing capacity, drafted in accordance with the WTO Decision of August 30, 2003. It establishes a sliding scale of 0.02 to $4 \%$ off the price of the generic product based on the country rank in the UN Human Development Indicator. For most developing countries the royalty rate is less than $3 \%$.

- The Tiered Royalty Method is different from the UNDP and The Canadian methods to determine royalty as it is not based upon the price of the generic

\footnotetext{
44 Implementation of Paragraph 6 of The Doha Declaration on The TRIPS Agreement and Public Health, WT/L/540, p. 1, para. 5.

45 TRIPS Agreement, art. 31(g).

46 Correa (n 30), p. 322.

47 James Love, 'Remuneration guidelines for non-voluntary use of a patent on medical technologies', World Health Organization, 2005, Washington D.C., paras. 19-28.
} 
product. Instead, the royalty is based upon the price of the patented product in the high-income country. The base royalty is $4 \%$ of the high-income country price which is then adjusted to account for relative income per capita or, four countries facing a particularly high burden of disease, relative income per person with the disease." 48

The right holder also has the possibility of review of the legal validity of any decision granting a Compulsory License, and/or of the determination of remuneration, by a judicial or a distinct higher authority. ${ }^{49}$ The obligation provided is limited to ascertaining the legal validity of the decision only. ${ }^{50}$

\section{Lack of manufacturing capacity (Article 31bis)}

Article 31 bis incorporates the WTO Decision of 30 August 2003 (hereinafter referred to as the Decision) and is the first amendment introduced to the TRIPS Agreement. It establishes a system of import and export which can be used in the event of "national emergency", "extreme urgency", or for "public non-commercial use". Least developed countries can use the system laid down in accordance with Article 31 bis to import pharmaceutical products under a compulsory license granted on any grounds determined by their national law. The Doha Declaration expressly confirms that they are free to determine such grounds which include public interest, public health emergency and refusal to deal.

Paragraph 6 of the Doha Declaration aims to enhance purchasing power and facilitate local production of pharmaceutical products. ${ }^{51}$ Eligible Importing Members may grant compulsory licenses to foster the capacity of their pharmaceutical industry as a sustainable way to address their health problems. It suggests that industrial and commercial policy objectives should not be pursued under the system established by the Decision but such objectives are not excluded altogether. This is because prospective suppliers under the Decision include private companies and such companies would not make the investment needed if there were no commercial benefits. ${ }^{52}$

The TRIPS Council recognizes two types of notifications: a general notification about the intention to be an eligible Importing Member, and a specific notification about the products that it intends to import, along with its required quantities, etc. Both these notifications are for the sake of transparency only, and are not authorization requests. In fact, Least Developed Countries are not required to make any notification of such intent. No WTO body is entitled to review, approve or reject a notification and the specific terms under which it is made.

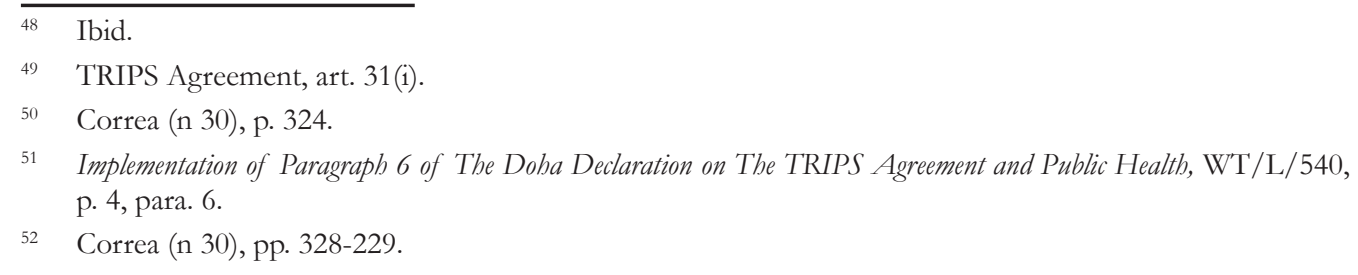


The quantity of drugs needed should be assessed as accurately as possible, since the exporting country can grant licenses for the specified amount only. The specification of quantity may be made on the basis of number of doses, quantity of active ingredients, and number of patients to be treated over a period of time or any other parameters. ${ }^{53}$ If a country underestimates its importing needs, the difference in the amount specified and the amount imported would not affect the validity of the issued compulsory license.

There are two ways to establish the lack of or insufficient manufacturing capacity of a Member country set out in the Annex to the Decision. The Member may either establish that it has no manufacturing capacity in the pharmaceutical sector; or when it has some manufacturing capacity but upon examination of this capacity, it is currently found to be insufficient to meet its needs. This requirement is not applicable to least developed countries.

Manufacturing capability includes both the technical capability and economic feasibility of such production. The Decision does not determine any particular criteria or methods of assessment to establish the lack of capacity. It is a matter of self-assessment and the outcome cannot be challenged by any other Member. It is also not subject to review or rejection by the TRIPS Council.

The Decision requires the granting of compulsory licenses in the exporting country. Under normal circumstances, it does not waive the need to request for a voluntary license to the patent. However, the exporting country may invoke a health emergency in a foreign country (the importing country) to waive the obligation to enter into prior negotiations.

The Decision also requires that the products to be supplied under the Decision should be clearly identifiable. Therefore, specific labelling, marks, shaping, and packaging of the product should be used to distinguish them. However, the obligation to distinguish products is not absolute. It can be omitted altogether when it is not feasible to distinguish the products, or when it has a significant impact on price ${ }^{54}$.

However, there are no parameters in the Decision to determine what "significant impact on price" means. The Decision does not specify who is going to assess the impact either. Though the suppliers are expected to make the assessment of the impact on price, they should take into account the purchaser's interests as well.

According to Paragraph 4 of the Decision, in order to ensure that the products imported under the system set out in the Decision are used for public health purposes, Member countries should take reasonable measures within their means. These measures should be proportionate to their administrative capacity, and to the risk of diversion of trade. This is required to prevent re-exportation of the products that have been imported into their territories under the system.

\begin{tabular}{ll}
\hline 53 & Ibid, p. 330. \\
54 & Ibid, p. 336.
\end{tabular} 
The purpose of the Decision would be defeated if the products are supplied and diverted from the markets for which they are intended. The obligation in this Paragraph is a best effort obligation. ${ }^{55}$ Developing and Least Developed Countries who experience difficulty in implementing this provision may request developed countries to provide technical and financial cooperation, which is required to be provided on mutually agreed terms and conditions.

\section{Prevailing Legislative Position}

Although the TRIPS Agreement lays down detailed guidelines for Compulsory Licensing, the Member countries have strikingly different legislative positions in their respective territories. And the situation in South Asia is no different. Even with the South-Asian group comprising eight countries, there is vast disparity in the legislative positions.

The TRIPS Ministerial Council, on 6 November 2015 decided to grant the Least Developed Countries (LDCs) of the World Trade Organisation a transitional period till 1 January 2033 to not give protection to pharmaceutical patents. ${ }^{56}$ However, despite there being four LDCs in South Asia (Afghanistan, Bangladesh, Nepal and Bhutan), no country has made an express declaration to abide by this transitional period. In fact, the closest neighbour to South Asia which has declared explicitly that it would be abiding by the transitional period is Myanmar. ${ }^{57}$

Since the national law would supersede the Decision, it is possible that these LDCs might decide to extend protection to pharmaceutical patents. Therefore, with regards to the topic at hand, it would be appropriate to discuss the prevailing legislative position of each country.

It should be noted that Maldives has no legislation protecting patents. Therefore, as a member of the WTO, intellectual property gets protection in Maldives under the TRIPS Agreement.

It should also be noted, that the Nepalese legislation has no provision for the grant of compulsory license. However, a patent application which has the likelihood of affecting public health may be rejected under Section 6 of Nepal's Patent, Design and Trade Mark Act, 2022 (1965).

An application for a Compulsory License is usually allowed after a certain period of time from the registration of the patent, considering the inventor's right to commercially

\footnotetext{
$55 \quad$ Ibid, p. 338.

56 'WTO members agree to extend Drug Patent exemptions for poorest members' World Trade Organisation, 6 November 2015, available at https://www.wto.org/english/news_e/news15_e/trip_06nov15_e.htm, accessed on 27 July 2020.

57 Daniel Collopy \& Yeo Moon Teng, 'Myanmar's New Patent Law' Spurson and Ferguson Intellectual Property, 13 February 2020, available at https://www.spruson.com/patents/myanmars-new-patent-law/, accessed on 27 July 2020.
} 
exploit his invention under normal circumstances. Although the TRIPS Agreement does not mention such a moratorium period, the Paris Convention specifies it to be four years since the patent application has been made, or three years since the grant of the patent, whichever expires later ${ }^{58}$

However, Bangladesh, Bhutan, Pakistan and Sri Lanka prescribe no such moratorium in their legislations. An application can be filed at any time if the sufficient grounds are met. India and Afghanistan, on the other hand, prescribe a moratorium of 3 years since the grant of the Patent. However, it should be noted that the Indian Patents Act, 1970 has a special provision which allows for this moratorium to be bypassed in cases of national emergency, public urgency or public non-commercial use under Section 92 of the Indian Patents Act, 1970.

As far as the grounds to apply for a compulsory license go, in Bangladesh, "inadequate use of the patent" as a ground for compulsory license is understood only in terms of the patent unfairly prejudicing any existing trade or industry or any new trade or industry from being established. It further includes prejudice caused due to unfair hire and purchase agreements for the patented article. The only provision under their legislation which comes closest to addressing the needs of the people in the times of a public health urgency is Section 25 of the Patents and Designs Act, 1911. It talks about revocation of the patent on the grounds of the alleged patent being "mischievous to the state or generally prejudicial to the public." ${ }^{59}$

On the other hand, the grounds available for Compulsory Licensing under Section 15 of Bhutan's Industrial Property Act of the Kingdom of Bhutan, 2001, are much broader and include national security, health, nutrition, protection of vital sectors of the economy and regulation of anti-competitive practices.

The grounds available under the Indian Patents Act, 1970 to file for a compulsory license include unreasonable pricing of the patent, non-working of the patent in India and the reasonable requirements of the people having not been satisfied. Apart from these, as discussed above, a compulsory license may be granted at any time after the registration of the patent if a circumstance of national emergency or a public urgency prevails, or if there is a case of public non-commercial use under Section 92 of the Indian Patents Act, 1970.

The Pakistan Patents Ordinance, 2000, under Section 58 allows for the exploitation of patents by the government or any authorized third party on the grounds of public interest, particularly nutrition and health.

The limitation to owner's rights under Section 86 of Sri Lanka's Intellectual Property Act, 2003 is perfectly harmonious with the provisions of the TRIPS Agreement.

The legislations of South-Asian countries, irrespective of whether there is a moratorium

\footnotetext{
58 Paris Convention for the Protection of Industrial Property, 26 April 1970,828 U.N.T.S. 305, Paris, 20 March 1883, art. 5(4).

59 Patents and Designs Act, 1911, Bangladesh, s. 25.
} 
or not, have provisions that provide for adequate remuneration to the patent holder. The adequacy shall be determined considering the commercial value of the patent. They also provide for the necessity of prior negotiations between the application maker and the patent holder. The Bhutanese legislation however, takes a slightly different approach with the minister being given the absolute power to decide on the grant of compulsory license after hearing the patent holder and any other parties concerned, if they wish to be heard (Section 15(1) (ii)). A similar approach is also adopted by the Pakistan Patents Ordinance, 2000 (Section 58(2)).

Afghanistan, Maldives and Bhutan are yet to accept the Doha Declaration. Apart from that, except India, no other south-Asian country has provisions relating to the export of patented pharmaceutical products (Section 92A), on the lines of the amendment to the TRIPS Agreement.

\section{Patent Pools}

Since a large number of government bodies and pharmaceutical companies are in the race to develop a vaccine and have invested tremendous amounts of money, it would not be incorrect to assume that the licensing fees and royalties for any vaccine(s) that make(s) a breakthrough would be too high. This would increase costs and make their availability in low income developing countries difficult. According to the World Bank, the average GDP per capita (which is often equated to income) of South Asian countries, as of 2019 is $\$ 1,989$ per annum; as against the global average of $\$ 18,381 .{ }^{60}$ Therefore, a large population of these countries would not be able to afford the vaccine if the prices are not controlled.

One way to ensure that the medicines are accessible to all is the creation of a "patent pool." This allows third parties to secure a non-exclusive license for the development of the patented product. Although Patent Pools have been used on a large scale in the field of artificial intelligence, it is a comparatively new concept in the field of public health and medicinal patents. ${ }^{61}$ To increase accessibility of antiretroviral drugs in poor and developing countries, the Medicines Patent Pool was established by Unitaid as the first public health patent pool in 2010. Its scope was later expanded to include Tuberculosis and Hepatitis $\mathrm{C}$ as well. ${ }^{62}$

In May 2016, the WHO submitted a report to the UN Secretary General High-Level Panel on Access to Medicines where it recommended that the scope of the Medicine Patent Pool be expanded and all the medicines in the list of WHO Essential Medicines

60 World Bank, 'GDP Per Capita-South Asia', available at https://data.worldbank.org/indicator/NY.GDP. PCAP.KD?locations $=8$ S, accessed on 28 July 2020.

61 Esteban Burrone, 'Patent Pooling in Public Health' in Margaret Chon, Pedro Roffe and Ahmed AbdelLatif (eds), The Cambridge Handbook of Public-Private Partnerships, Intellectual Property Governance, and Sustainable Development, Cambridge University Press, 2018, UK, 1st edition, 2018, p. 93.

62 Burrone et. al., 'Patent Pooling to increase access to essential medicines' 97(8) Bulletin of the World Health Organization 2019, available at https://www.who.int/bulletin/volumes/97/8/18-229179.pdf, accessed on 3 August 2020. 
also be licensed into the Medicine Patent Pool. ${ }^{63}$

The Medicines Patent Pool realised the catastrophe created by the COVID-19 pandemic and on $31^{\text {st }}$ March 2020, decided to temporarily expand its scope to include "any bealth technology that could contribute to the global response to COVID-19 and where licensing could facilitate innovation and access." 64

The urgency of such global solidarity was also recognized by the World Health Assembly in its $73^{\text {rd }}$ session where a key aspect of the resolution was to collaboratively work through "existing mechanisms for voluntary pooling and licensing of patents." Although the US and UK were of the opinion that patent protection should not be compromised, other major economies such as the EU, China were of the view that all measures should be taken to ensure that any breakthrough should be accessible to all.

Apart from this, on the proposal of Costa Rica, the WHO recently launched the COVID-19 Technology Access Pool (C-TAP). It aimed to create a technology pooling platform which lifted barriers to the access to medicines, vaccines and other health care products against COVID-19. ${ }^{65}$ This was launched with the support of 37 countries and is voluntary in nature. ${ }^{66}$ It seeks to make all tools required for response to COVID-19 available as "global public goods."

However, major economies such as the US and UK have not shown support to C-TAP. In fact, the only South-Asian countries which endorsed C-TAP were Pakistan and Sri Lanka. According to the WHO, C-TAP consists of five elements:

(a) public disclosure of gene sequences and data; (b) transparency of clinical trial results; (c) conditions attached to public funding of pharmaceutical companies; (d) promotion of open innovation; and (e) technology transfer. ${ }^{67}$

\section{Challenges Due to Collaborative Innovation and Multiple Patents}

Traditionally, innovators had a very secretive approach with regards to the process of

63 'WHO submission to the United Nations Secretary General high-level panel on access to medicines' World Health Organization, 7 March 2016, available at https://static1.squarespace.com/ static/562094dee4b0d00c1a3ef761/t/56e746279f7266a586c2b893/1457997352055/WHO_HLP_ Submission_7Mar2016.pdf, accessed 29 July 2020.

${ }^{64}$ 'The Medicines Patent Pool and Untaid respond to access efforts for COVID-19 treatments and technologies' Medicines Patent Pool, 31 March 2020, available at https://medicinespatentpool.org/newspublications-post/the-medicines-patent-pool-and-unitaid-respond-to-access-efforts-for-covid-19treatments-and-technologies/, accessed on 29 July 2020.

${ }_{65}$ WHO and Costa Rica Preview Technology Pooling Initiative to Ensure Access to COVID-19 Healthcare Products for All' World Health Organisation, 15 May 2020, available at https://www.who.int/news-room/ detail/15-05-2020-who-and-costa-rica-preview-technology-pooling-initiative-to-ensure-access-to-covid19-health-products-for-all, accessed on 29 July 2020.

66 William Worley, 'WHO and Costa Rica launch COVID-19 Technology Access Pool', Devex, 29 May 2020), available at https://www.devex.com/news/who-and-costa-rica-launch-covid-19-technology-accesspool-97368, accessed 30 July 2020.

67 Ibid. 
innovation. However, with technological advancements, increasing needs of the people and the time constraints involved, innovators are taking a collaborative approach, with multiple stakeholders being involved in an invention. This is more relevant in the times of COVID-19 where the majority of vaccines are being developed under collaborative research. ${ }^{68}$ It should also be noted that in cases of collaborative innovation, the nature and scope of the contribution by each stakeholder may vary. One innovator may lead the research with the other just assisting in securing the required raw materials, funds, etc.

When an inventor secures patent protection over his invention, they have the absolute right to decide upon its commercial exploitation. ${ }^{69}$ However, in case of a jointly owned patent, multiple stakeholders are involved which makes the management of the patent difficult. For example, the US allows for the co-owner to exploit the patent and license it without the consent of the other owners ${ }^{70}$ majority of the other jurisdictions mandate prior consent of the other co-owners.

However, the requirement of consent for license of patented technology is varying. For example, China does not mandate the consent of other co-owners while granting a non-exclusive license. ${ }^{71}$ However, the revenue earned by the co-owner who decides to unilaterally license the patent needs to be shared equally by all co-owners. India, on the other hand mandates prior consent of all co-owners in all forms of licensing agreements which a co-owner seeks to enter into. ${ }^{72}$ The Controller of Patents acts as a mediator in case of any dispute. ${ }^{73}$ However, since the scope of this paper is limited to the Compulsory licensing provisions, express consent for the granting of the license becomes immaterial.

Also, since multiple inventions take place while developing a vaccine, there is a possibility that a single application may be filed for all the inventions which relate to the creation of the vaccine, which is also sometimes called an "omnibus specification". ${ }^{74}$ Alternatively, different applications could be filed for each invention for increasing business credibility and revenue. With the majority of potential COVID-19 vaccines being collaborative innovations, filing separate applications for every invention would only add complexities to the licensing procedure, thereby leading to delayed delivery of the vaccine to the needy.

68 'Public Statement for Collaboration on COVID-19 Vaccine Development' World Health Organisation, 13 April 2020, available at https://www.who.int/news-room/detail/13-04-2020-public-statement-forcollaboration-on-covid-19-vaccine-development, accessed on 1 August 2020.

69 'Patents', World Intellectual Property Organisation, available at https://www.wipo.int/patents/en/, accessed on 24 January 2021.

70 Title 35 of United States Code, 1952, United States of America, s. 262.

71 Patent Law of the People's Republic of China, 1984, China, s. 2.

72 Indian Patents Act, 1970, India, s. 50.

73 Indian Patents Act, 1970, India, s. 51.

74 'Merits \& Demerits of Multiple Inventions in A Single Patent Application' Intepat, 27 April 2020, available at https://www.intepat.com/blog/patent/multiple-inventions-in-a-single-patent-application-meritsdemerits/, accessed on 1 August 2020. 


\section{Suggestions}

The analysis of the TRIPS Agreement provision makes it clear that the procedure to grant compulsory licenses under TRIPS Agreement is not complex and lengthy. The procedural requirements of Article 31 are minimal and capable of efficiently dealing with situations of extreme urgency or national emergency. However, there are certain concerns with the position in South Asia which need to be effectively remedied.

As far as Bhutan goes, since it is still a non-member of the WTO, the flexibilities under the TRIPS Agreement will not be available to it. In fact, paragraph 7 of the Doha Declaration which talks about technology transfer to LDCs, extends this provision to "Member LDCs only". In such a situation, the only plausible solution the authors see for Bhutan is to join a patent pool where a voluntary non-exclusive license of a patented invention could be granted to it. The authors further suggest that apart from granting a license, the scope of Patent Pools created for dealing with the pandemic should be expanded to include export of patented products to Members of the pool with no manufacturing abilities.

As far as the case of Nepal goes, its national legislation has no provision for Compulsory Licensing or government use. Therefore, the only way it can utilize the Doha Amendments successfully is by notifying itself as an eligible Importing Member. It will also have to specify the required quantity of the drug which can be a challenging exercise. The amendment mandates that if a patented product is being exported under a compulsory license, remuneration to the patent holder is to be paid by the exporting country on the basis of the use of the patented product in the importing country.

A similar approach of notifying itself as an eligible Importing Member would have to be adopted by Maldives since it has no National IP legislation and hence, no means to grant a Compulsory License.

The grounds for Compulsory Licensing under the Patents and Designs Act, 1911 of Bangladesh are extremely narrow. In fact, there is no mention of the words 'health', 'nutrition' or 'well-being' anywhere in the Act. The only possible remedy which the authors could deduce was the rejection of the patent on the ground of it being "mischievous to the state" or "generally prejudicial to the public." However, this would be a highly criticized measure. The authors are therefore of the opinion that Bangladesh should amend its legislation and allow for a Compulsory License to be granted on the grounds of public health, harmonious to those laid down in the TRIPS Agreement.

Pakistan and Sri Lanka have TRIPS compatible legislations. They can use the flexibility of the TRIPS Agreement to ensure vaccine availability to their people.

India is the only South-Asian country with innovative and manufacturing capabilities and it is known globally to have a humanitarian approach towards making pharmaceuticals available at reasonable prices. Not only are its Compulsory Licensing provisions perfectly compatible with the TRIPS Agreement but it is also the only South-Asian country to have express provision on granting of Compulsory Licenses for exporting (Section $92 \mathrm{~A}$ ). With a vaccine trial being underway in India as well, it is India's responsibility to 
ensure that its neighbouring countries are not deprived of the access to any successful breakthroughs.

A potential scale of determining remuneration which balances the interests of the manufacturers and countries can be developed by combining the best elements of the pre-existing scales. A sliding scale from $0.02 \%$ to $4 \%$ of the price of the patented product can be used. Least Developed Countries would be required to pay $0.02 \%$ royalty whereas high income developed countries could be charged up to $4 \%$. The calculation of the remuneration should take into account the actual cost of production, the healthcare budget of the country, estimated number of affected individuals in the country, government contribution to the research and development, etc. Additional parameters may also be used to arrive at an adequate remuneration.

On the point of collaborative innovation, although the consent of the joint-owners of the Patent is immaterial, it is the view of the authors that every co-owner should have an opportunity of putting forth its contentions to the grant of the Compulsory License. In order to avoid internal conflicts, the stakeholders should come to terms and lay down a clear and unambiguous cooperation agreement in order to make sure that there is no dispute with regards to sharing of royalties. Since different bodies involved might have different proportions of contribution, the share of the royalties should also be decided accordingly.

In order to ease the licensing complexities, the ideal solution could be filing a single application for the multiple inventions which are involved in the creation of the vaccine. However, since this could result in losing out on business credibility and goodwill which comes with having multiple patents. Therefore, the authors suggest the voluntary formation of a collective management organization by the joint-owners of various patents on the lines of EU model of Collective Management Organisations for copyrights. ${ }^{75}$

This collective management organization would enter into voluntarily by all the rightholders and shall sufficiently represent each right holder. The terms of agreement of the formation of such an organization could be modelled upon the existing contracts or agreements between patent-holders who are collaborating for the development of the vaccine. The organization shall collect royalties, monitor use of the patent, and if necessary, negotiate and enter into voluntary agreements on behalf of the right holders.

This system can promote transparency, increase bargaining power of the various rightholders and promote healthy competition and reduced government intervention. This also benefits potential licensees as it makes the process of obtaining a license less cumbersome and expensive.

On the point of Patent Pooling, it is not unusual for leading pharmaceutical manufacturers and developed countries to oppose the idea because of the tremendous

\footnotetext{
75 Directive 2019/790 on copyright and related rights in the Digital Single Market, 2019, European Parliament and Council, p.1.
} 
capital invested in research and the comparatively low returns they might get. Patent protection is a necessary tool to bolster innovation, which is important in the present times. However, learning from the delayed access of AIDS medicines to low-income countries, a mechanism which balances the rights of the patent holder and public welfare needs to be developed.

In this regard, while the authors applaud the global solidarity towards combating the pandemic in the form of Patent Pools, there is also a need for adequate remuneration and recognition for the contributors of this pool. An additional term of patent protection could be granted after the pandemic is unlikely to recur to such inventions.

Although the prevailing Compulsory Licensing regime across South Asia is diverse, there are sufficient means to ensure that it can be utilised effectively to provide access to medicines. A large number of inventors have decided to make their inventions available for free in order to combat the virus. In fact, well known multinational corporations have started an 'Open COVID Pledge ${ }^{76}$ where innovators make a pledge to make their inventions relating to the fight with COVID-19 freely available. However, it should be noted that not a single big pharmaceutical company has signed it yet.

The end to this battle with COVID-19 is not in sight yet. However, with a balanced intellectual property rights framework in place, we take many steps forward in our preparedness for it and for any such situation which might arise in the Post-COVID world.

$76 \quad$ Eddie Powell \& Tim Wright, 'The Open COVID Pledge' Fladgate, 30 April 2020, available at https://www. fladgate.com/2020/04/the-open-covid-pledge/, accessed on 3 August 2020. 